Abstract-With the use of a baited stereo-video camera system, this study semiquantitatively defined the habitat associations of 4 species of Lutjanidae: Opakapaka (Pristipomoides filamentosus), Kalekale ( $P$. sieboldii), Onaga (Etelis coruscans), and Ehu (E. carbunculus). Fish abundance and length data from 6 locations in the main Hawaiian Islands were evaluated for speciesspecific and size-specific differences between regions and habitat types. Multibeam bathymetry and backscatter were used to classify habitats into 4 types on the basis of substrate (hard or soft) and slope (high or low). Depth was a major influence on bottomfish distributions. Opakapaka occurred at depths shallower than the depths at which other species were observed, and this species showed an ontogenetic shift to deeper water with increasing size. Opakapaka and Ehu had an overall preference for hard substrate with low slope (hard-low), and Onaga was found over both hard-low and hardhigh habitats. No significant habitat preferences were recorded for Kalekale. Opakapaka, Kalekale, and Onaga exhibited size-related shifts with habitat type. A move into hardhigh environments with increasing size was evident for Opakapaka and Kalekale. Onaga was seen predominantly in hard-low habitats at smaller sizes and in either hard-low or hard-high at larger sizes. These ontogenetic habitat shifts could be driven by reproductive triggers because they roughly coincided with the length at sexual maturity of each species. However, further studies are required to determine causality. No ontogenetic shifts were seen for Ehu, but only a limited number of juveniles were observed. Regional variations in abundance and length were also found and could be related to fishing pressure or large-scale habitat features.

Manuscript submitted 11 August 2012. Manuscript accepted 9 July 2013. Fish. Bull. 111:293-308 (2013). doi: 10.7755/FB.111.4.1

The views and opinions expressed or implied in this article are those of the author (or authors) and do not necesarily reflect the position of the National Marine Fisheries Service, NOAA.

\title{
Establishing species-habitat associations for 4 eteline snappers with the use of a baited stereo-video camera system
}

\author{
William F. X. E. Misa (contact author) ${ }^{1}$ \\ Jeffrey C. Drazen ${ }^{1}$ \\ Christopher D. Kelley ${ }^{2}$ \\ Virginia N. Moriwake ${ }^{1}$
}

Email address for contact author: wfmisa@hawaii.edu

1 Department of Oceanography

School of Ocean and Earth Science and Technology

University of Hawaii at Manoa

1000 Pope Rd., MSB 205

Honolulu, Hawaii 96822

Present address for contact author: Fisheries Research and Monitoring Division

Pacific Islands Fisheries Science Center

National Marine Fisheries Service, NOAA

2570 Dole St.

Honolulu, HI 96822

2 Hawaii Undersea Research Laboratory

School of Ocean and Earth Science and Technology

University of Hawaii at Manoa

1000 Pope Rd., MSB 303

Honolulu, Hawaii 96822

The catch of deepwater fisheries comprises a multitude of species that live on continental slopes and deep topographic oceanic structures, such as seamounts, ridges, and banks to depths below $2000 \mathrm{~m}$. In the IndoPacific region, deepwater snappers (Lutjanidae), groupers (Serranidae), and jacks (Carangidae) that inhabit deep slopes and seamounts at depths of 100-400 m make up a major component of this fishery. The deepwater handline or "bottomfish" fishery of Hawaii also targets these groups of fishes (Haight et al., 1993a). Some of the commercially important bottomfish species can live in excess of 35 years (Andrews et al., 2011; Andrews et al., 2012) - a longevity that indicates low rates of natural mortality and susceptibility to overfishing (Haight et al., 1993a). Four of these key bottomfish species are the focus of this study: Crimson Jobfish (Pristipomoides filamentosus), Lavender Jobfish (Pristipomoides sieboldii), Flame Snapper (Etelis coruscans), and Ruby Snapper (Etelis carbun- culus). In Hawaii, these species are known by a different set of common names, and these names will be used for simplicity throughout this article. Pristipomoides filamentosus is commonly called Opakapaka, $P$. sieboldii is called Kalekale, E. coruscans is called Onaga, and E. carbunculus is called Ehu. Opakapaka and Onaga rank first and second in total landed weight and value in the Hawaiian Archipelago, and the smaller species, Ehu and Kalekale, are abundant but lower in value and landings (WPRFMC ${ }^{1}$ ).

From the late $1980 \mathrm{~s}$ to early 2000s, the Division of Aquatic Resources (DAR) of the Hawaii Department of Land and Natural Resources (DLNR) and the Western Pacific Re-

${ }^{1}$ WPRFMC (Western Pacific Regional Fishery Management Council). 2006. Bottomfish and seamount groundfish fisheries of the western Pacific region, 2005 annual report, 113 p. [Available from Western Pacific Regional Fishery Management Council, 1164 Bishop Street, Suite 1400, Honolulu, HI 96813.] 


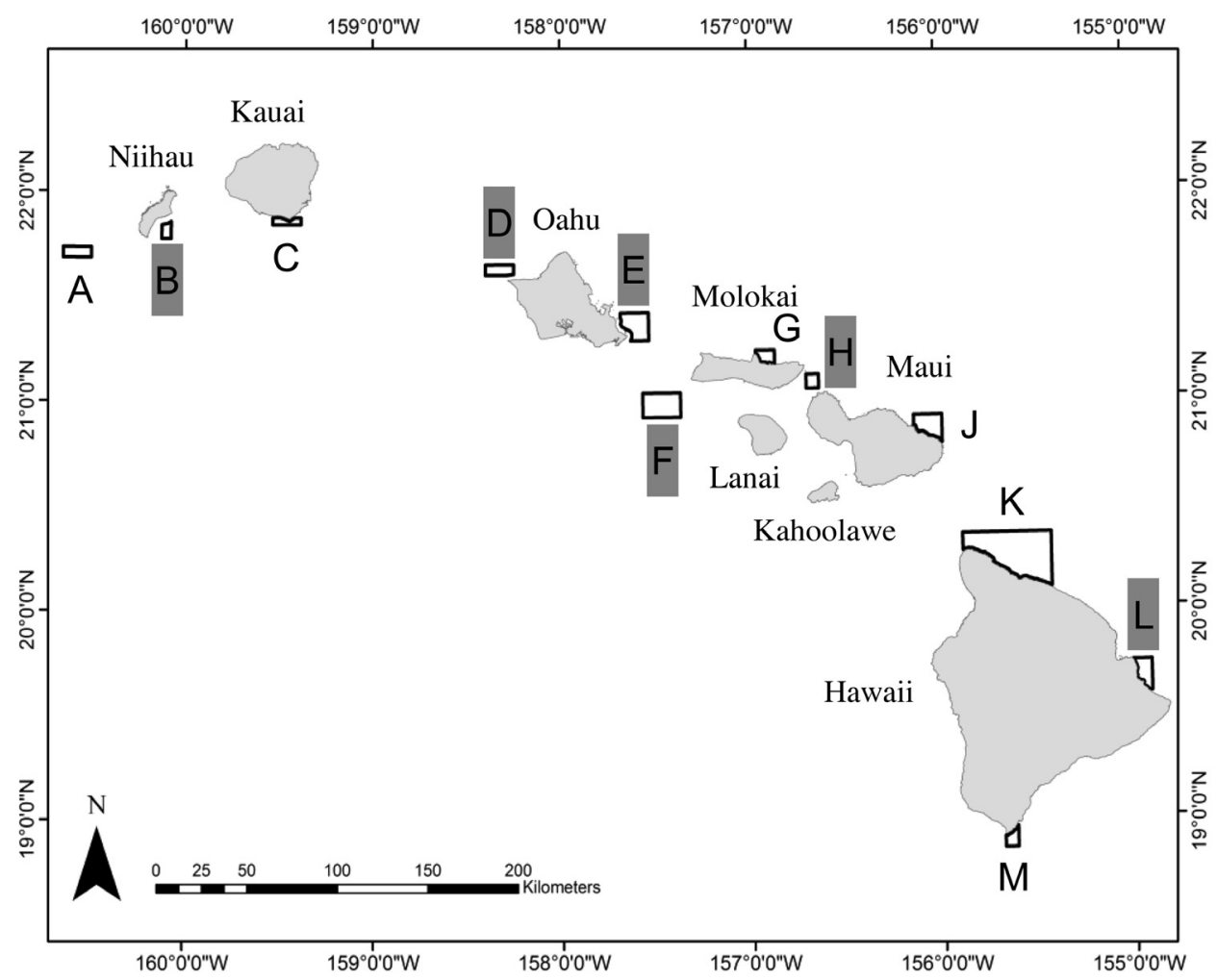

Figure 1

Map of the current bottomfish restricted fishing areas (BRFAs) in the main Hawaiian Islands. Highlighted letters indicate the 6 BRFAs-(B) Niihau, (D) Kaena, (E) Makapuu, (F) Penguin Bank, (H) Pailolo Channel, and (L) Hilo-that were sampled from May 2007 to June 2009 with the use of a baited stereo-video camera system for the study of the habitat associations of 4 snapper species.

gional Fishery Management Council (WPRFMC) assessed bottomfish stocks in the main Hawaiian Islands (MHI) by calculating their estimated spawning potential ratios (SPRs) from annual commercial catch data and established the critical threshold for designation of a stock in a state of recruitment overfishing at a SPR of $20 \%$. Two bottomfish species, the Onaga and Ehu, had SPRs well below $20 \%$ for most of this period $\left(\mathrm{DAR}^{2}\right)$ and were, therefore, considered to be in a state of recruitment overfishing.

In 1996, the Magnuson-Stevens Fishery Conservation and Management Act imposed a mandate on regional fishery councils to restore the stocks of overfished species to healthy levels (i.e., SPR $>20 \%$ ) within a 10 -year time period. To address this problem, the WPRFMC turned to the DAR, which created 19 bottomfish restricted fishing areas (BRFAs) and prohibited bottomfishing in them (Div. Aquatic Resources, Department of Land

2 DAR (Division of Aquatic Resources). 2006. Hawaii's bottomfish fishery, Land Board briefing paper, 17 p. [Available from Division of Aquatic Resources, Hawaii Department of Land and Natural Resources, 1151 Punchbowl St., Rm. 330, Honolulu, HI 96813.] and Natural Resources, Chapter 13-94, Bottomfish Management, Hawaii Administrative Rules). These BRFAs, which took effect on June 1, 1998, were designed to protect $20 \%$ of deepwater areas in the depth range of 100 $400 \mathrm{~m}$, where most Onaga and Ehu are found (Parke, 2007). However, identification of suitable geographic areas for closure was difficult at that time because of a lack of adequate habitat data-a common problem for most deepwater fisheries given the logistical challenges involved in sampling the deep sea.

In 2007, the DAR revised the BRFA system with data from surveys conducted with a multibeam sonar system, fishing surveys, and analysis of video collected during surveys with a submersible-all of which provided a great deal of new information on bottomfish habitats. The original BRFAs established in 1998 were retained, expanded, relocated, or opened to fishing, and the 12 BRFAs established in 2007 (Fig. 1) contained significantly more of the hard, steep habitat believed to be preferred by most bottomfish species (Parke, 2007). This belief was formed on the basis of results from submersible and fishing surveys that found some species in the water column adjacent to areas of high relief, such as underwater headlands, ledges, outcrops, and pinnacles 
(Ralston et al., 1986; Haight et al., 1993a). More recent submersible surveys have supported those studies and have indicated that substrate type may be an important factor that influences distributions of adult bottomfishes (Kelley et al., 2006). However, information on species-specific and age-specific habitat associations for bottomfishes remains limited. Although the preferred habitat of juvenile Opakapaka has been observed to be soft substrates with little to no relief (Moffitt and Parrish, 1996; Parrish et al., 1997), variations in habitats between adults and juveniles, if any, have yet to be identified for other species of deepwater bottomfishes.

Information that can identify fish-habitat associations is fundamental to fisheries science. In addition to the requirement to improve overfished stocks, the Magnuson-Stevens Act required federal fishery management plans to identify the essential fish habitat (EFH) for their managed species (Rosenberg et al., 2000). The $\mathrm{EFH}$ for the bottomfish fishery in Hawaii currently is designated as depths from 0 to $400 \mathrm{~m}$ without speciesspecific habitat requirements, despite the notion that habitat requirements probably differ between bottomfish species and ontogenetic stage of these species. To guide management decisions on the protection and sustainable use of bottomfish resources in Hawaii, this EFH designation should be as complete and as specific as possible (Kelley et al., 2006).

New data are needed to obtain a greater understanding of the habitat associations of bottomfish species. Common shallow-water sampling techniques, such as diver transects, however, are not logistically feasible at depths below $100 \mathrm{~m}$, and fishing surveys can be destructive to local populations. The need for a different survey method has led to the emergence of baited camera systems as cost-effective, nonextractive tools for the estimation of relative abundances of fish species at depths $>100 \mathrm{~m}$ (Merritt et al., 2011; Moore et al., 2013).

With the use of a baited stereo-video camera system, we aimed to improve our understanding of the habitat associations of 4 species of bottomfishes, within different size classes, in the MHI. Data specific to each species can be used to assess the amount of suitable habitat present in management areas and to relate catch per unit of effort (CPUE) to habitat type. Most important, through expansion of our understanding of the ecology of bottomfishes, more specific and refined EFH designations can be forged and ecosystem-based management strategies can be further developed.

\section{Materials and methods}

The Bottom Camera Bait Station (BotCam) developed by the Coral Reef Ecosystem Division of the NOAA Pacific Islands Fisheries Science Center is a remote, fully automated, baited system with stereo-video cameras; it was designed specifically for nonextractive, fisheryindependent sampling of deepwater bottomfish species in their habitat and depth range (Merritt, 2005; Merritt et al., 2011). The method for sampling fish populations with a baited stereo-video camera system has been found to generate more consistent data than have comparable unbaited systems (Harvey et al., 2007), has the ability to detect mobile fish species (Harvey et al., 2007; Watson et al., 2010), and has been determined to be effective in sampling bottomfishes in Hawaii (Ellis and DeMartini, 1995; Merritt et al., 2011). The BotCam is a means by which bottomfish abundance estimates can be made within actual bottomfish habitats and fish lengths can be accurately measured.

Upon deployment, the BotCam sits about $3 \mathrm{~m}$ off the bottom of the seafloor, and, depending on the depth of deployment, amount of light, and water clarity, the field of view may expand or contract. Moore et al. (2013) estimated that the visual area sampled by the BotCam was between 4 and $400 \mathrm{~m}^{2}$. The BotCam makes use of ambient light, which allows for an operating depth of up to $300 \mathrm{~m}$ and is operational on multiple bottom types, including steep slopes and high relief. In our study, the BotCam recorded 30 to 45 min of continuous video at each of the 6 deployment locations. Depth data were taken from a conductivity, temperature, and depth profiler attached to the system. The bait canister attached to the BotCam was filled with $\sim 800 \mathrm{~g}$ of ground anchovy and squid, a mix that is similar to the bait used by bottomfish fishermen (Merritt et al., 2011).

Bottomfish habitat types in the MHI were characterized with multibeam bathymetry and backscatter data that originated from a variety of mapping surveys conducted with multibeam sonar systems in and around the MHI since the late 1990s. The U.S. Geological Survey in collaboration with the Monterey Bay Aquarium Research Institute carried out the first survey in the MHI in 1998 (U.S. Geological Survey Digital Data Series DDS-55, http://pubs.usgs.gov/dds/dds-55/ index.html; MBARI Hawaii Multibeam Survey, http:// www.mbari.org/data/mapping/hawaii/index.htm) with a $30-\mathrm{kHz}$ Simrad $^{3}$ EM 300 multibeam sonar system (Kongsberg Maritime AS, Kongsberg, Norway). Both the bathymetry and backscatter data from this survey were processed at a grid resolution of $20 \mathrm{~m}$. The majority of the remaining data came from subsequent surveys conducted from 2002 to 2006 by researchers at the Hawaii Undersea Research Laboratory, University of Hawaii at Manoa, with a 95-kHz Simrad EM 1002 multibeam sonar system. The editing and processing of raw data were carried out by the Hawaii Mapping Research Group of the University of Hawaii at Manoa using the SABER multibeam editing program (SAIC, Inc., McLean, VA) and other proprietary software. Bathymetry data were processed at a $20-\mathrm{m}$ grid resolution, and backscatter data were processed at either a $10-\mathrm{m}$ resolution or a $20-\mathrm{m}$ resolution, depending on the survey. The processed

\footnotetext{
${ }^{3}$ Mention of trade names or commercial companies is for identification purposes only and does not imply endorsement by the National Marine Fisheries Service, NOAA
} 
data from these cruises have not been made publicly available, with the exception of the bathymetry data that have been incorporated into a 50-m-resolution synthesis of the entire MHI that is available from the Hawaii Mapping Research Group (http://www.soest.hawaii. edu/hmrg/multibeam/index.php).

Multibeam backscatter data in grids with a $20-\mathrm{m}$ resolution cannot be used effectively to identify specific substrate types, such as mud, sand, pebbles, cobbles, boulders, and bedrock, because more than one of these substrate types often can be found on the seafloor in an area of $20 \times 20 \mathrm{~m}$. Similarly, more than one type of slope can be found in areas of that size because of the presence of small carbonate ledges, large boulders and blocks, sand dunes, and other small-scale topographic features common to seafloors in the Hawaiian Archipelago. Multibeam data values for each grid cell $(20 \times 20 \mathrm{~m})$ are typically derived through calculation of either the Gaussian weighted means (bathymetry) or the medians (backscatter) of the sonar footprints within each cell. For these reasons, only 4 general habitat types were derived from these multibeam data: hard substrate with high slope (hard-high), hard substrate with low slope (hard-low), soft substrate with high slope (soft-high), and soft substrate with low slope (soft-low). Bathymetry data from the different sonar systems generally were consistent.

After a number of slope analyses were conducted in ArcGIS 9.1 (Esri, Redlands, CA), a value of $20^{\circ}$ was determined to be a reasonable boundary between the high and low slopes that appeared in the bathymetry images. Backscatter data, however, are often inconsistent between systems with different frequencies. Furthermore, the backscatter data used in this study were processed in different ways by different technicians. As a result, boundary values between hard and soft substrates had to be determined on a basis of per system and per cruise. A value of 187 was used as the boundary between hard and soft substrates for the EM 300 data and was validated through examination of video from submersible surveys. Boundary values for the EM 1002 data ranged from -41 to 150 and were established through comparison of areas of overlap with EM 300 data and analysis of video from submersible surveys.

Habitat was classified at a resolution of $200 \times 200 \mathrm{~m}$ for areas in and around BRFAs. Polygons for high and low slopes and hard and soft substrates were generated with the Raster calculator in ArcGIS 9.1. Intersects of slope and hardness resulted in polygons for the 4 habitat types. A grid cell $(200 \times 200 \mathrm{~m})$ was superimposed over these polygons, and the areas of the habitat types within each grid cell were calculated. Each grid cell was assigned a habitat type on the basis of which habitat type was observed in the greatest proportion in that area.

A stratified-random sampling approach was used to select locations for BotCam sampling. Although the purpose of our study was to evaluate species-habitat associations, another goal of this project was to evaluate population changes inside and outside of BRFAs. This objective affected our sampling design. We used data from 625 deployments of the BotCam conducted inside and outside of 6 of the 12 current BRFAs (Fig. 1) between May 2007 and June 2009. The 6 BRFAs that were sampled are located off Niihau (BRFA B), Kaena (BRFA D), Makapuu (BRFA E), and Penguin Bank (BRFA F), in Pailolo Channel (BRFA H), and outside of Hilo (BRFA L). The Niihau and Hilo BRFAs were areas of continued closure from the initial implementation of BRFAs in 1998. The Makapuu and Penguin Bank BRFAs were expanded versions of smaller preexisting BRFAs from 1998, and the BRFAs off Kaena and in Pailolo Channel were areas newly closed in 2007.

The BotCam was lowered to depths of 100-300 m. Although the EFH for deep bottomfishes in Hawaii extends to $400 \mathrm{~m}$, the video cameras work under ambient light to only $300 \mathrm{~m}$, thus limiting the depth range of our sampling. Sampling effort was weighted toward known preferred bottomfish habitats to ensure greater replication where fish densities were expected to be higher. Because previous studies have found bottomfishes associated with hard substrates, high slopes, or a combination of both (Polovina et al., 1985; Ralston et al., 1986; Haight et al., 1993a; Parke, 2007), for our study, hardhigh habitats were considered the most suitable and soft-low habitats the least suitable. To sample a BRFA, 32 BotCam deployments inside and 32 outside but adjacent to a BRFA were completed over grids of each habitat type with the following replication: 12 hardhigh, 8 hard-low, 8 soft-high, and 4 soft-low. BotCam deployments targeted centroids of randomly selected grid cells $(200 \times 200 \mathrm{~m})$ and were kept a minimum of 400 $\mathrm{m}$ apart to reduce the likelihood of sampling overlap. In regions where a given habitat type was not present, sampling intensity was increased in the next most suitable habitat. This approach led to skewed sampling across habitat types in Pailolo Channel because only low-slope habitats were identified at a resolution of $200 \times 200 \mathrm{~m}$. When BotCam deployments did not yield usable video (e.g., no recordings or extremely dark imagery), the BotCam was redeployed at that location on another day. As often happens during sampling efforts in the field, not all targeted grids were sampled because of weather and equipment issues. In the 2-year sampling period covered by this study (2007-09), 4 of the 6 BRFAs (Niihau, Makapuu, Penguin Bank, and Pailolo Channel) were sampled twice and the Kaena and Hilo BRFAs were sampled only once.

BotCam video footage was reviewed in the laboratory to estimate the relative abundance, recorded as the maximum number of a particular species observed in a single frame of video (MaxNo), of Opakapaka, Kalekale, Onaga, and Ehu with VF Deep Portal (Deep Development Corp., Sumas, WA) and Adobe Premiere Pro CS4 (Adobe Systems, Inc., San Jose, CA) software programs. Fishes were identified to the most specific taxonomic classification possible with a species identification reference (Randall, 2007). MaxNo is a conservative abun- 
dance estimate that avoids the potential problem of counting the same fish multiple times as it re-enters a camera's field of view. Many studies have determined that MaxNo is positively correlated with fish density (Ellis and DeMartini, 1995; Priede and Merrett, 1996; Willis et al., 2000; Willis and Babcock, 2000; Yau et al., 2001; Cappo et al., 2003). This parameter also has been found to be highly correlated with the traditional parameter of CPUE used in fishing surveys (Ellis and DeMartini, 1995). MaxNo was recorded for all fishes present in the BotCam video footage, but only data for the 4 species of interest were analyzed.

Permutational analysis of variance (PERMANOVA) of the data was performed in Primer 6 (PRIMER-E Ltd., Ivybridge, UK) with PERMANOVA+ (Anderson et al., 2008). With PERMANOVA, the data are not assumed to be normally distributed; therefore, this technique was deemed appropriate for analysis of our data, which included a highly skewed (overdispersed) relative abundance distribution due to an unbalanced experimental design and frequent zero counts. The 4 species considered in our study do not all occupy the entire depth range sampled (Polovina et al., 1985; Haight, 1989; Everson et al., 1989; Merritt et al., 2011). To constrain the data to an appropriate range for each species, the depths at which each species had its greatest MaxNo had to be identified. For the initial analysis, depth was divided into $30-\mathrm{m}$ bins from 90 to $300 \mathrm{~m}$. Relative abundance values were square-root transformed to compensate for numerous zero counts and occasional large numbers. A Euclidean distance matrix was used in the statistical test with a type-III sum of squares. If a significant difference $(P<0.05)$ was observed across depth bins, a subsequent pair-wise PERMANOVA was performed to determine the preferred depths of each species. Subsequent analyses (MaxNo and fork length [FL]) were then constrained to the depth preferences identified for each of the 4 species studied.

Through identification of habitat preferences, the influence of BRFA location (i.e., combined area inside and outside a BRFA) and protection (i.e., area inside versus outside a BRFA) could not be overlooked. PERMANOVA in a 3-way crossed design was used to determine how BRFA location (BR, 6 levels, fixed), protection (PR, 2 levels, fixed), habitat type (HA, 4 levels, fixed), and the interaction of these factors affected the relative distribution of each species. MaxNo values were square-root transformed, and the PERMANOVA was run on a Euclidean distance matrix with type-III sum of squares. Where significant results $(P<0.05)$ occurred, pair-wise testing was performed to identify specific differences.

For individual fish visible in both BotCam cameras, FL was measured with stereo-photogrammetric measurement software: Visual Measurement System 7.5 (Geometric Software Pty. Ltd., Coburg, Victoria,

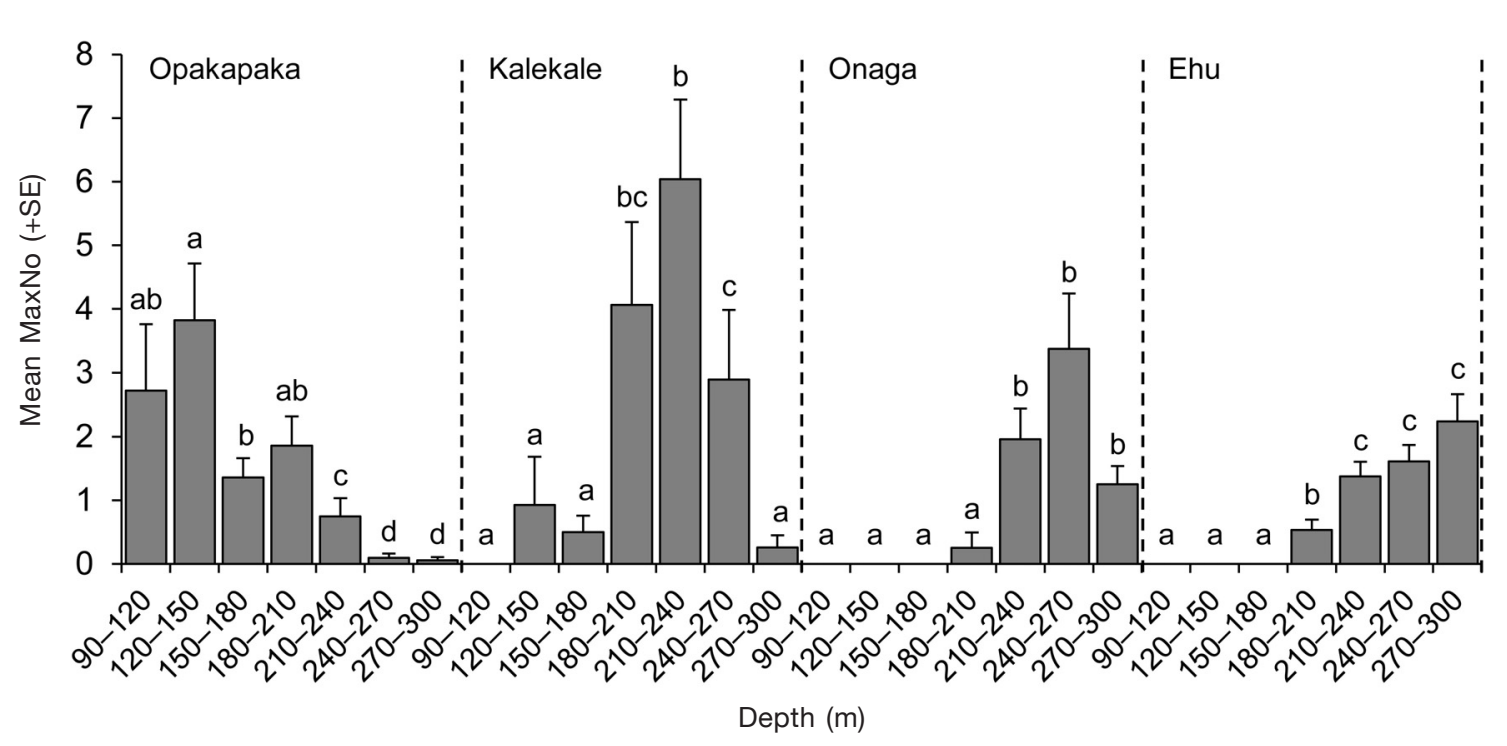

Figure 2

Mean relative abundance (MaxNo) with standard error (SE) across 7 depth bins for Opakapaka (Pristipomoides filamentosus), Kalekale (P. sieboldii), Onaga (Etelis coruscans), and Ehu (E. carbunculus) from surveys of these species conducted in the main Hawaiian Islands from May 2007 to June 2009 with the use of a baited stereo-video camera system. Columns with the same letter are not significantly different from each other $(P>0.05$, post hoc permutational analysis of variance [PERMANOVA] testing). Error bars indicate $\pm 1 \mathrm{SE}$ of the mean. 


\section{Table 1}

Results of permutational analysis of variance (PERMANOVA) with relative abundance (MaxNo) data from our surveys of 4 species-Opakapaka (Pristipomoides filamentosus), Kalekale (P. sieboldii), Onaga (Etelis coruscans), and Ehu (E. carbunculus)_in the main Hawaiian Islands between May 2007 and June 2009. The following factors were tested within the preferred depths of each species: bottomfish restricted fishing area location (BR), protection (PR), and habitat type (HA). Preferred depths are noted in the column head for each species. $\mathrm{df}=$ degrees of freedom; $F=$ PERMANOVA $F$-statistic; $P=$ PERMANOVA $P$-value. Asterisks indicate statistical significance at $P<0.05$.

\begin{tabular}{|c|c|c|c|c|c|c|c|c|c|c|c|c|}
\hline \multirow[b]{2}{*}{ Factor } & \multicolumn{3}{|c|}{$\begin{array}{l}\text { Opakapaka } \\
(90-210 \mathrm{~m})\end{array}$} & \multicolumn{3}{|c|}{$\begin{array}{c}\text { Kalekale } \\
(180-270 \mathrm{~m})\end{array}$} & \multicolumn{3}{|c|}{$\begin{array}{c}\text { Onaga } \\
(210-300 \mathrm{~m})\end{array}$} & \multicolumn{3}{|c|}{$\begin{array}{c}\text { Ehu } \\
(210-300 \mathrm{~m})\end{array}$} \\
\hline & $\mathrm{df}$ & $F$ & $P$ & $\mathrm{df}$ & $F$ & $P$ & $\mathrm{df}$ & $F$ & $P$ & df & $F$ & $P$ \\
\hline $\mathrm{BR}$ & 5 & 2.86 & $0.02^{*}$ & 5 & 2.07 & 0.09 & 5 & 1.54 & 0.17 & 5 & 4.78 & $0.00 *$ \\
\hline PR & 1 & 0.00 & 1.00 & 1 & 0.07 & 0.79 & 1 & 0.07 & 0.78 & 1 & 0.31 & 0.58 \\
\hline HA & 3 & 8.28 & $0.00 *$ & 3 & 1.68 & 0.18 & 3 & 3.87 & $0.02^{*}$ & 3 & 2.83 & $0.04^{*}$ \\
\hline $\mathrm{BR} \times \mathrm{PR}$ & 5 & 0.63 & 0.66 & 5 & 0.55 & 0.72 & 5 & 0.56 & 0.70 & 5 & 0.81 & 0.54 \\
\hline $\mathrm{BR} \times \mathrm{HA}$ & 13 & 0.64 & 0.80 & 12 & 1.89 & 0.06 & 13 & 0.69 & 0.71 & 13 & 2.33 & $0.01 *$ \\
\hline $\mathrm{PR} \times \mathrm{HA}$ & 3 & 0.62 & 0.59 & 3 & 0.87 & 0.45 & 3 & 0.56 & 0.62 & 3 & 0.93 & 0.42 \\
\hline $\mathrm{BR} \times \mathrm{PR} \times \mathrm{HA}$ & 12 & 1.02 & 0.42 & 10 & 0.44 & 0.91 & 9 & 0.59 & 0.76 & 9 & 0.58 & 0.79 \\
\hline Residual & 247 & & & 282 & & & 295 & & & 295 & & \\
\hline
\end{tabular}

Australia) and PhotoMeasure 1.74 (SeaGIS Pty. Ltd., Bacchus Marsh, Victoria, Australia). Measurements of individual fish were taken at the point of MaxNo or at the point in the video where the most fish could be measured to ensure that individuals were not repeatedly measured at various times during video analysis. Replicate measurements were taken for individual fish to increase the accuracy of the measurement. An LED device was used to ensure synchronicity of the video footage from the left and right cameras. A rootmean-square error or residual parallax $>10 \mathrm{~mm}$ and a precision-to-FL ratio $>10 \%$ were indicative of inaccurate measurements. To ensure the quality of fish length data, these measurements were removed from the analyses in this study. The same 3-way crossed design from the PERMANOVA of relative abundance (BR, PR, HA) was used to test FLs for each species. Transformation of FLs, however, was not necessary because these data typically were normally distributed.

Because only variations in mean length were evaluated with the previously described approach, additional analyses were undertaken to investigate size-related changes in habitat association. A linear regression was used to evaluate the relationship between depth and FL for each of the 4 species studied to identify ontogenetic shifts with depth. As part of our examination of ontogenetic shifts across habitat types, a contingency table (tested with Pearson's chi-square test) was used to determine whether the size-class distribution of each species was independent of habitat type. Fork lengths were grouped into $10-\mathrm{cm}$ bins. This size interval was chosen to maximize the number of observations in each size bin. Merritt et al. (2011) tested and found measurements from BotCam video to be accurate to within $0.3-0.9 \mathrm{~cm}$, making such a grouping very robust.

\section{Results}

For all 4 species studied, significant differences in relative abundance were found across depth bins (PERMANOVA, $P<0.05)$. Pair-wise comparisons of MaxNo from the 7 depth bins highlighted the depth preference of each species (Fig. 2). MaxNo was highest from 90 to $210 \mathrm{~m}$ for Opakapaka (post hoc PERMANOVA, $P<0.05$ ). The preferred depths of Kalekale were 180-270 m, and both Onaga and Ehu had the deepest range among species at 210-300 $\mathrm{m}$ (post hoc PERMANOVA, $P<0.05$ ).

Within the preferred depths of a species, either BRFA location, habitat type, or the interaction of these 2 factors had an effect on the relative abundance of 3 of the 4 species studied (Table 1). Protection and the interaction of all other factors with protection, however, did not have an effect (PERMANOVA, $P>0.05$ ). BRFA location and habitat type were each significant factors for Opakapaka. Hilo had the highest relative abundance of this species among sampled locations, and hard-low habitats yielded greater abundance estimates for Opakapaka than other habitat types (Fig. 3; post hoc PERMANOVA, $P<0.05)$. Although no significant location or habitat effects were observed for Kalekale, the interaction of BRFA location and habitat type was marginal ( $P=0.06$; Table 1$) ; 2$ of the largest counts of this species (100 and 85 individuals) occurred on hard-high habitats at Niihau and led to a high mean MaxNo (Fig. 3).

Habitat type was the only factor that affected the relative abundance of Onaga. Hard substrate habitats, with either high or low slope, had greater mean MaxNo for Onaga than soft substrate habitats (Fig. 3; post hoc PERMANOVA, $P<0.05)$. BRFA location, habitat type, and the interaction of these 2 factors were significant 


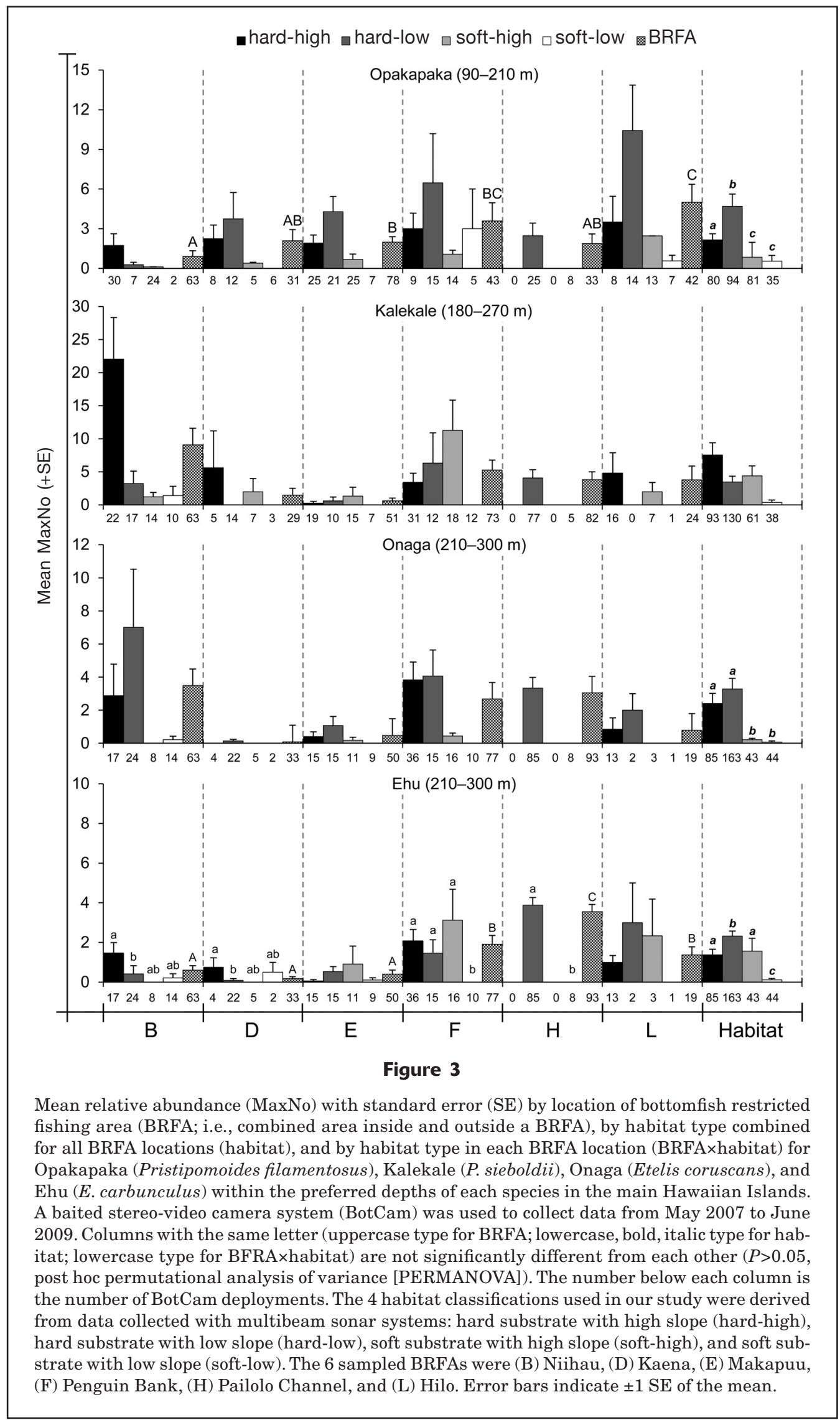




\section{Table 2}

Results of permutational analysis of variance (PERMANOVA) with fork length data from our surveys of 4 speciesOpakapaka (Pristipomoides filamentosus), Kalekale (P. sieboldii), Onaga (Etelis coruscans), and Ehu (E. carbunculus)_in the main Hawaiian Islands between May 2007 and June 2009. The following factors were tested within the preferred depths of each species: bottomfish restricted fishing area location (BR), protection (PR), and habitat type (HA). Preferred depths are noted in the column head for each species. $\mathrm{df}=$ degrees of freedom; $F=$ PERMANOVA $F$ statistic; $P=$ PERMANOVA $P$-value. Asterisks indicate statistical significance at $P<0.05$.

\begin{tabular}{|c|c|c|c|c|c|c|c|c|c|c|c|c|}
\hline \multirow[b]{2}{*}{ Factor } & \multicolumn{3}{|c|}{$\begin{array}{l}\text { Opakapaka } \\
(90-210 \mathrm{~m})\end{array}$} & \multicolumn{3}{|c|}{$\begin{array}{c}\text { Kalekale } \\
(180-270 \mathrm{~m})\end{array}$} & \multicolumn{3}{|c|}{$\begin{array}{c}\text { Onaga } \\
(210-300 \mathrm{~m})\end{array}$} & \multicolumn{3}{|c|}{$\begin{array}{c}\text { Ehu } \\
(210-300 \mathrm{~m})\end{array}$} \\
\hline & $\mathrm{df}$ & $F$ & $P$ & $\mathrm{df}$ & $F$ & $P$ & $\mathrm{df}$ & $F$ & $P$ & $\mathrm{df}$ & $F$ & $P$ \\
\hline $\mathrm{BR}$ & 5 & 36.04 & $0.00 *$ & 5 & 28.20 & $0.00 *$ & 4 & 11.05 & $0.00 *$ & 4 & 4.90 & $0.00 *$ \\
\hline PR & 1 & 14.24 & $0.00 *$ & 1 & 1.43 & 0.23 & 0 & \multicolumn{2}{|c|}{ No test } & 0 & \multicolumn{2}{|c|}{ No test } \\
\hline HA & 3 & 11.39 & $0.00 *$ & 3 & 18.38 & $0.00^{*}$ & 1 & 0.48 & 0.49 & 2 & 1.77 & 0.17 \\
\hline $\mathrm{BR} \times \mathrm{PR}$ & 5 & 2.02 & 0.08 & 3 & 16.57 & $0.00 *$ & 3 & 4.82 & $0.00 *$ & 4 & 0.84 & 0.52 \\
\hline $\mathrm{BR} \times \mathrm{HA}$ & 9 & 7.66 & $0.00 *$ & 4 & 1.16 & 0.33 & 1 & 23.69 & $0.00 *$ & 5 & 1.62 & 0.16 \\
\hline $\mathrm{PR} \times \mathrm{HA}$ & 2 & 0.45 & 0.64 & 2 & 0.21 & 0.82 & 2 & 0.48 & 0.61 & 2 & 1.31 & 0.27 \\
\hline $\mathrm{BR} \times \mathrm{PR} \times \mathrm{HA}$ & 5 & 3.42 & $0.01^{*}$ & 2 & 0.21 & 0.81 & 1 & 13.26 & $0.00 *$ & \multicolumn{2}{|c|}{ 0No test } & \\
\hline Residual & 419 & & & 446 & & & 242 & & & 274 & & \\
\hline
\end{tabular}

for Ehu. The highest relative abundance for this species was in Pailolo Channel, and the lowest levels were seen at Niihau, Kaena, and Makapuu (Fig. 3; post hoc PERMANOVA, $P<0.05)$. Overall, hard-low habitats had significantly greater numbers of Ehu than did other habitat types. By BRFA location and habitat type, the mean MaxNo of Ehu in Pailolo Channel was higher for hard-low than for soft-low habitats, and similar abundance estimates were found for hard-high, hardlow, and soft-high habitats on Penguin Bank. Niihau and Kaena differed from the other sampled locations in that hard-high habitats had a greater relative abundance of Ehu than did hard-low habitats.

In our evaluation of mean lengths, BRFA location, protection, and habitat type were all important factors, and the interactions between them were sometimes significant (Table 2). BRFA location, protection, habitat type, the interaction of BRFA location and habitat type, and the interaction of all 3 factors were significant for Opakapaka. Niihau had the largest Opakapaka on average $(65.29 \mathrm{~cm} \mathrm{FL)} \mathrm{among} \mathrm{sampled} \mathrm{locations,} \mathrm{and}$ the smallest Opakapaka (28.35 cm FL; Fig. 4; post hoc PERMANOVA, $P<0.05)$ were seen at Hilo. The smallest individual at Hilo measured $\sim 16 \mathrm{~cm} \mathrm{FL}$, and the largest individual at Niihau was $\sim 79 \mathrm{~cm} \mathrm{FL}$. Opakapaka from outside protected areas had a mean length of $42.89 \mathrm{~cm}$ FL and were larger than those fish observed inside the sampled BRFAs (40.53 cm FL; PERMANOVA, $P<0.05$ ). The smallest mean lengths of this species were found over hard-low habitats compared with other habitat types overall, other habitats at each BRFA location, and other habitats either inside or outside a particular BRFA (Fig. 4; Table 3; post hoc PERMANOVA, $P<0.05$ ).

BRFA location, habitat type, and the interaction of BRFA location and protection were significant for Kale- kale. Pair-wise comparisons showed that this species had its smallest mean length (23.64 cm FL) at Kaena, was largest in hard-high habitats $(31.46 \mathrm{~cm} \mathrm{FL})$ and smallest in soft-low habitats ( $8.64 \mathrm{~cm} \mathrm{FL,} n=2)$, and was larger inside the Penguin Bank and Pailolo Channel BRFAs and outside the Hilo BRFA than in other sampled areas (Fig. 4; Table 3; post hoc PERMANOVA, $P<0.05)$. The smallest individual Kalekale, however, measured $7.63 \mathrm{~cm} \mathrm{FL}$ at Niihau. BRFA location, the interaction of BRFA location with protection, the interaction of BRFA location with habitat type, and the interaction of all 3 of these factors were significant for Onaga. Mean length for Onaga was smallest in Pailolo Channel (42.80 cm FL) than at other locations (Fig. 4) but larger inside the Pailolo Channel BRFA than outside this protected area (Table 3 ; post hoc PERMANOVA, $P<0.05)$. The smallest individual Onaga measured $15.05 \mathrm{~cm}$ FL. Although the interaction of BRFA location and habitat type and the interaction of BRFA location, protection, and habitat type had significant results for Onaga, no clear trends were seen. BRFA location was the only factor that had an influence on mean length for Ehu (Table 2; PERMANOVA, $P<0.05$ ). Overall, mean sizes were very similar for this species but were smallest at Makapuu and Hilo (Fig. 4).

For all sampled locations combined, size-related shifts in species-habitat associations were evident. The linear regressions of FL against depth for each species showed that size increased with depth for Opakapaka (coefficient of determination $\left[r^{2}\right]=0.438$, $P<0.01$ ) but did not for the other 3 species (Fig. 5). In our evaluation of the proportion of fish measured in each habitat type by size class, habitat associations clearly varied by size for Opakapaka, Kalekale, and Onaga (Fig. 6). Ehu had very similar habitat associa- 


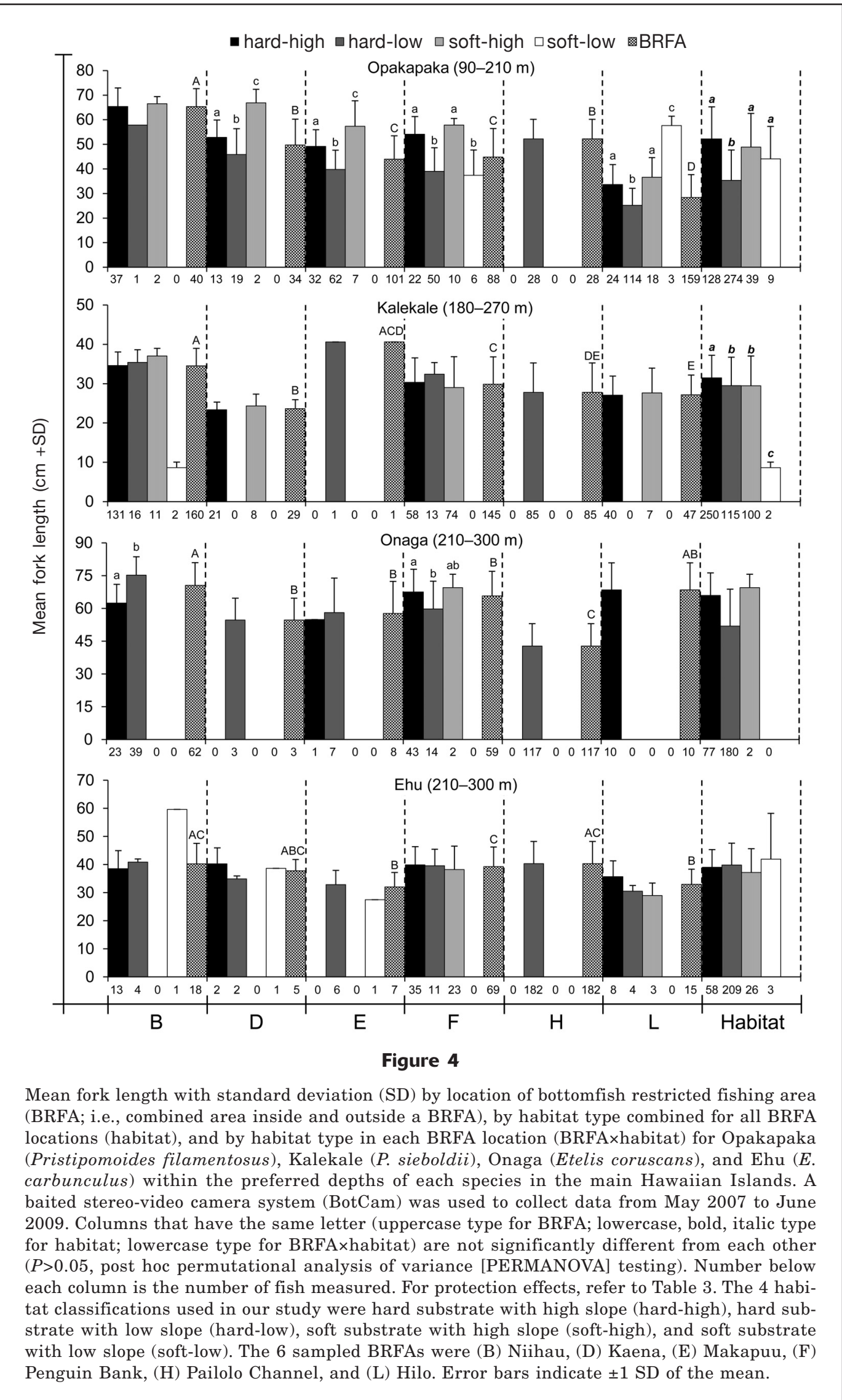




\section{Table 3}

Summary of significant comparisons from post hoc permutational analysis of variance (PERMANOVA) of fork lengths for bottomfish restricted fishing area location (BR), protection (PR), habitat type (HA), and the interaction of these factors for Opakapaka (Pristipomoides filamentosus), Kalekale (P. sieboldii), Onaga (Etelis coruscans), and Ehu (E. carbunculus) within the preferred depths of each species from our study of these species in the main Hawaiian Islands between May 2007 and June 2009. Locations of the 6 BRFAs where sampling was conducted are the following: Niihau (B), Kaena (D), Makapuu (E), Penguin Bank (F), Pailolo Channel (H), and Hilo (L). Protection is designated as inside (in) or outside (out) a BRFA. Habitat types are hard-high (HH), hard-low (HL), soft-high (SH), soft-low (SL). NS=nonsignificant comparisons. Preferred depths are noted under the species name in the first column.

\begin{tabular}{|c|c|c|c|c|c|c|c|}
\hline & $\mathrm{BR}$ & PR & HA & $\mathrm{BR} \times \mathrm{PR}$ & $\mathrm{BR} \times \mathrm{HA}$ & $\mathrm{PR} \times \mathrm{HA}$ & $\mathrm{BR} \times \mathrm{PR} \times \mathrm{HA}$ \\
\hline $\begin{array}{l}\text { Opakapaka } \\
(90-210 \mathrm{~m})\end{array}$ & $\begin{array}{l}\text { Largest } \\
\text { in B } \\
\text { Smallest } \\
\text { in L }\end{array}$ & $\begin{array}{l}\text { Larger } \\
\text { outside }\end{array}$ & $\begin{array}{l}\text { Smallest } \\
\text { in HL }\end{array}$ & NS & $\begin{array}{l}\text { (D) largest in SH, } \\
\text { smallest in HL } \\
\text { (E) largest in SH, } \\
\text { smallest in HL } \\
\text { (F) largest in high slope, } \\
\text { smallest in low slope } \\
\text { (L) largest in SL, } \\
\text { smallest in HL }\end{array}$ & s. & $\begin{array}{l}(\mathrm{D} \text { in) } \mathrm{SH}>\mathrm{HL} \\
(\mathrm{E} \text { in) } \mathrm{HH}, \mathrm{SH}>\mathrm{HL} \\
(\mathrm{E} \text { out) } \mathrm{SH}>\mathrm{HH}>\mathrm{HL} \\
(\mathrm{F} \text { in) } \mathrm{HH}, \mathrm{SH}>\mathrm{HL} \\
(\mathrm{F} \text { out) } \mathrm{HH}, \mathrm{SH}>\mathrm{SL} \\
(\mathrm{L} \text { in) } \mathrm{HH}>\mathrm{HL} \\
(\mathrm{L} \text { out }) \mathrm{SL}>\mathrm{HH}>\mathrm{SH}>\mathrm{HL}\end{array}$ \\
\hline $\begin{array}{l}\text { Kalekale } \\
(180-270 \mathrm{~m})\end{array}$ & $\begin{array}{l}\text { Smallest } \\
\text { in D }\end{array}$ & NS & $\begin{array}{c}\text { Largest } \\
\text { in } \mathrm{HH}\end{array}$ & $\begin{array}{l}\text { (F) larger inside } \\
\text { (H) larger inside } \\
\text { (L) larger outside }\end{array}$ & NS & NS & NS \\
\hline $\begin{array}{l}\text { Onaga } \\
(210-300 \mathrm{~m})\end{array}$ & $\begin{array}{l}\text { Smallest } \\
\text { in } \mathrm{H}\end{array}$ & No test & NS & (H) larger inside & $\begin{array}{l}\text { (B) larger in HL } \\
\text { than } \mathrm{HH} \\
\text { (F) similar mean size }\end{array}$ & NS & $\begin{array}{l}(\mathrm{B} \text { in) } \mathrm{HL}>\mathrm{HH} \\
(\mathrm{F} \text { in) } \mathrm{HH}>\mathrm{HL}\end{array}$ \\
\hline $\begin{array}{l}\text { Ehu } \\
(210-300 \mathrm{~m})\end{array}$ & $\begin{array}{l}\text { Similar } \\
\text { mean size }\end{array}$ & No test & NS & NS & NS & NS & No test \\
\hline
\end{tabular}

tions in all size classes and did not show any habitat shifts with size (Pearson's chi-square, $P>0.05$ ). Opakapaka had a shift from hard-low habitats to hard-high habitats with an increase in size. There was a greater proportion of sexually mature individuals $(\geq 43 \mathrm{~cm} \mathrm{FL}$; Kikkawa, 1984) for this species over hard-high habitats, and individuals $<43 \mathrm{~cm} \mathrm{FL}$ were seen mostly in hard-low habitats. Although less evident than the habitat shift by Opakapaka, a habitat shift by Kalekale to hard-high from other habitat types was observed within the size class of $25-35 \mathrm{~cm}$. Onaga and Ehu were recorded mostly in hard-low habitats in all size classes. For Onaga, however, the smallest individuals ( $<55 \mathrm{~cm}$ FL) were found only in hard-low habitats, and, as size increased, hard-high habitats were equally dominant for this species.

\section{Discussion}

Depth has a significant influence on the distribution of bottomfishes in Hawaii. Two distinct depth groupings were seen within the sampling range of this study. Opakapaka was dominant in the shallower end of the sampling depths $(<200 \mathrm{~m})$, and Kalekale, Onaga, and Ehu were observed more frequently toward the deep- er end $(>200 \mathrm{~m})$. This finding is consistent with that of previous studies in Hawaii (Haight, 1989; Everson et al., 1989; Merritt et al., 2011) and in the Mariana Archipelago (Polovina et al., 1985). When establishing species-specific differences in distribution, depth must be the first factor evaluated.

Although the limitations of our sampling methods have been discussed in previous studies (e.g., Merritt et al., 2011; Moore et al., 2013), it is important to review them here before further discussion of our results. The absence of a quantifiable sampling area, variability in the field of view of the BotCam, and the scale at which habitats were classified are confounding factors that limit the interpretation of the results of this study to a semiquantitative nature. Because the BotCam makes use of ambient light and because environmental conditions, such as water clarity can differ from site to site, variability in the visual area sampled was unavoidable. However, unlike other visual survey methods, where quadrats or transect lines are used, this approach reduces, but does not eliminate, the effect of visual area because it relies on attracting fishes close to the cameras. What may be more important is the effect of the attracting bait-odor plume.

It was our working assumption that any fish seen on BotCam video was from the targeted grid area 


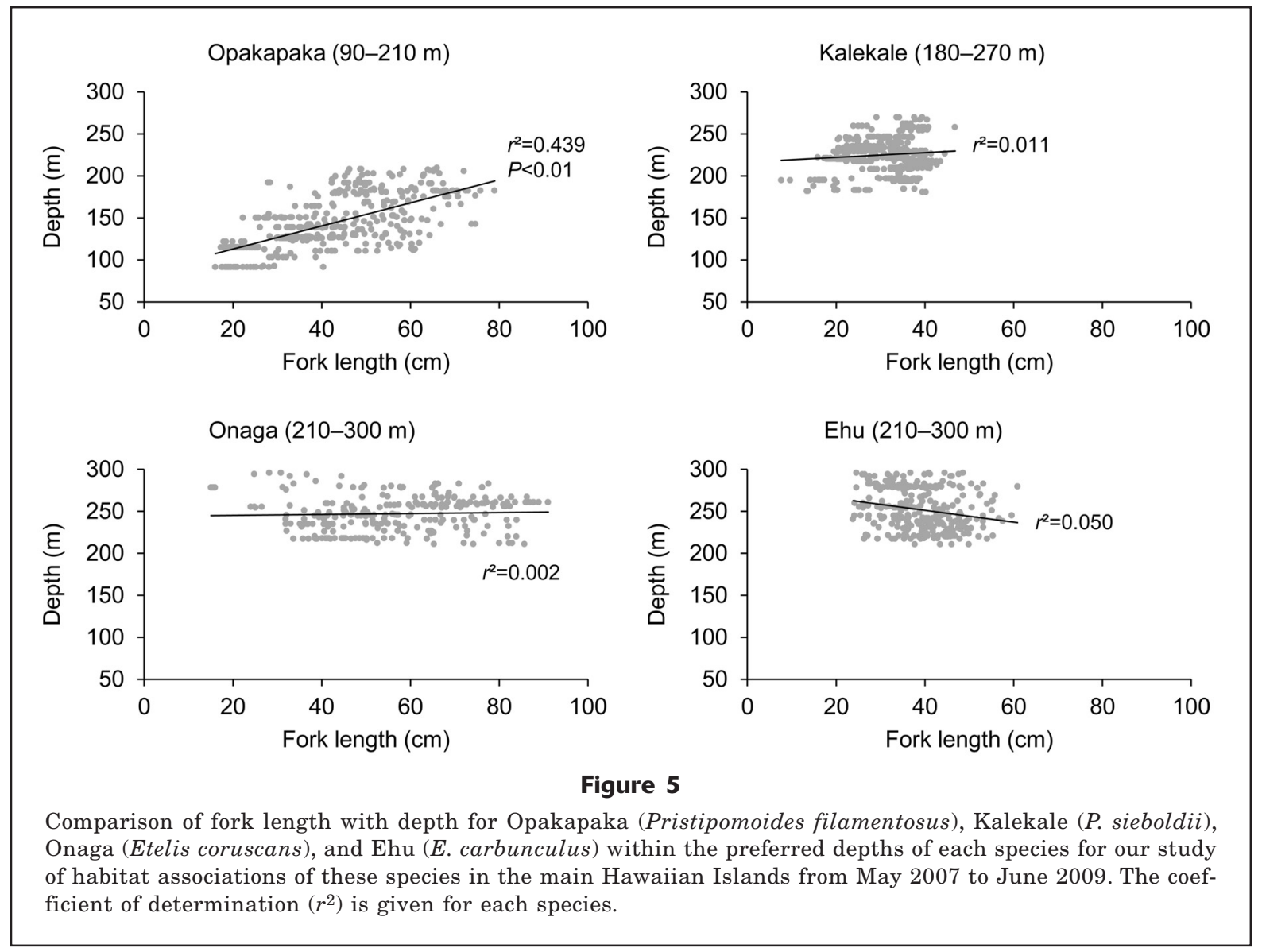

$(200 \times 200 \mathrm{~m})$ regardless of the visual area observed in the video. This assumption was made on the basis of the limited information available on the distance of bottomfish attraction to bait stations. Ellis and DeMartini (1995) estimated that the greatest distance of attraction for juvenile Opakapaka to their baited cameras was between 48 and $90 \mathrm{~m}$. Merritt et al. (2011), in their baited camera survey of Penguin Bank, used a 200-m distance between deployment locations to avoid a cross influence of bait.

The area of fish attraction (sampling area) has been quantified at abyssal depths by Priede and Merrett (1996) through the use of current velocity, fish swimming speed, and a bait dispersal model. Their determination of the area of attraction, however, relied on assumptions (i.e., fish are evenly dispersed) that do not apply to the fish species and shallower depth ranges in this study. Furthermore, bottom current variability, habitat variability, and small-scale bathymetric features at mesophotic depths around Hawaii make the quantification of the area of attraction to bait extremely challenging. In a comparison of baited and unbaited underwater video stations, Harvey et al. (2007) acknowledged that fish behavior and life history also may affect attraction to bait. All the species in this study are regularly attracted to bait and are taken on baited hooks, but other behavioral traits (e.g., mobility, schooling, and reproductive cycles) could affect speciesspecific responses to a bait-odor plume. Given the difficulty involved in the determination of the actual area of bait influence, the appropriateness of the habitatclassification scale chosen for use in this study cannot be evaluated. Until an effective scale of attraction can be verified for deepwater snappers and other bottomfishes, a fully quantitative assessment of species-habitat associations is not yet possible.

Although previous studies have indicated that habitats with hard substrates and high slopes, such as headlands and promontories, are preferred by many bottomfish species (Ralston and Polovina, 1982; Ralston et al., 1986; Parrish, 1987; Kelley et al., 2006; Parke, 2007), we determined that other habitat types, such as hard-low habitats, are important to eteline snappers and that species-specific differences in habitat preference exist. On the basis of relative abundance, we found that the overall habitat preference of Opakapaka was for low-sloping hard substrates. Onaga was associated with hard-high and hard-low habitats, and Ehu was seen mostly on hard-low habitats. The observed association of juvenile Opakapaka and Onaga with hard-low habitats may be driving their preference for this habitat type. In contrast, the finding for Ehu could 


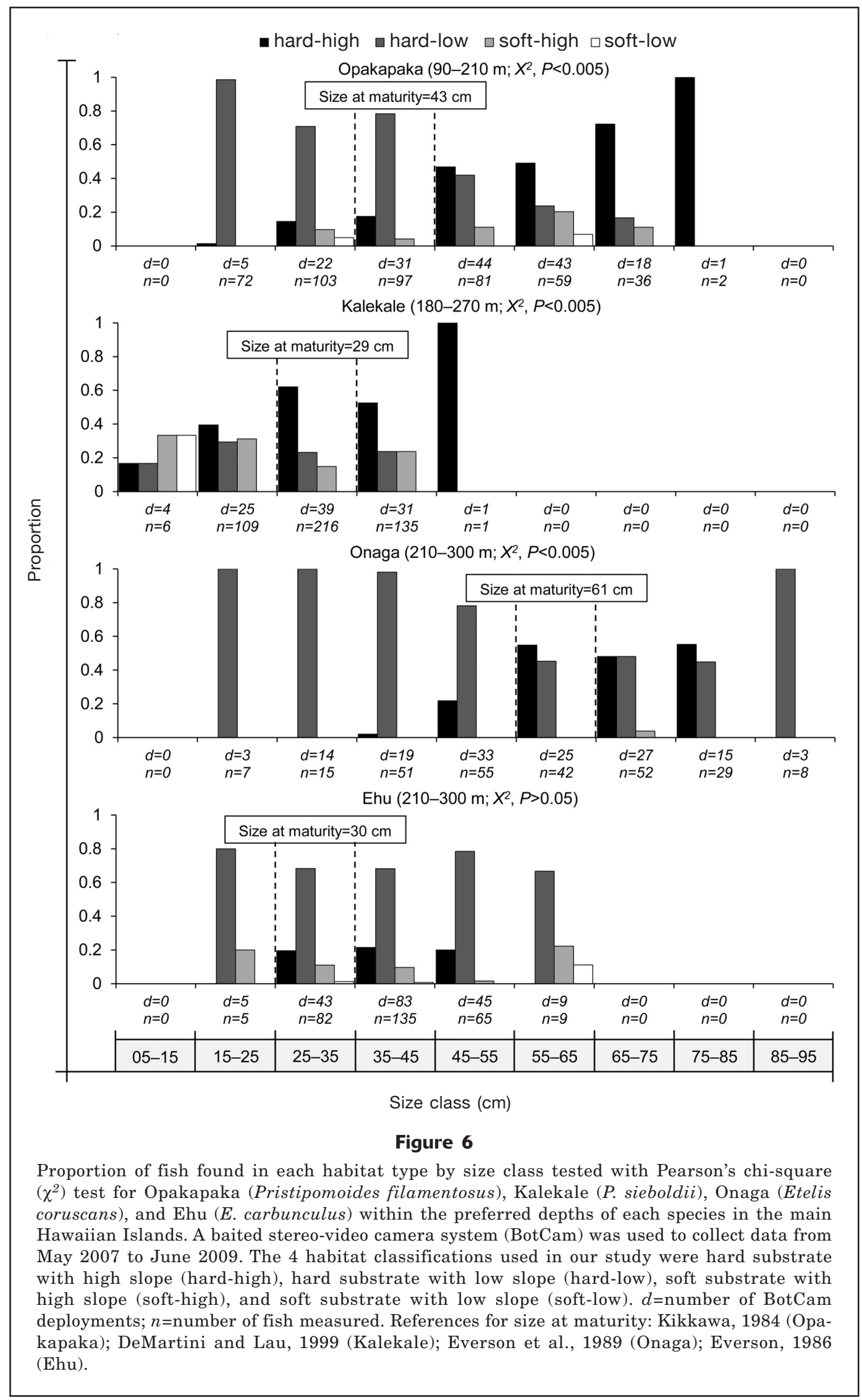


have been the result of a sampling artifact caused by the lack of habitat types other than the hard-low environments in Pailolo Channel, where many observations of this species were made. Regardless, the results of this study clearly show the importance of this habitat type for Ehu. Kalekale were observed often in large schools in our video footage. For defense against predators, this species may rely on its schooling behavior instead of associating with the bottom habitat. The lack of a significant habitat preference for Kalekale could, consequently, be driven by this defense mechanism. Assessment of species-habitat associations, therefore, requires an understanding of species behaviors and the changes in habitat use by life stage.

Clear ontogenetic shifts in habitat associations were evident for 3 of the 4 species studied. For Opakapaka, there was a distinct ontogenetic progression in habitat association that expands what is known for this species. The known habitat for juveniles of this species at 7-25 cm FL is shallow, low-sloping, soft substrates (Moffitt and Parrish, 1996). Juvenile Opakapaka have been observed at depths of 65-100 m offshore of Kaneohe Bay (Parrish, 1989; Moffitt and Parrish, 1996) and more recently off Waikiki, Oahu, at depths of 37-42 m (J. Drazen, unpubl. data). These juveniles move out of their nursery grounds and presumably merge with the adult schools in deeper waters after about 1 year (Parrish et al., 1997). Within the preferred depth range identified in our study for Opakapaka (90-210 m), the smallest mean lengths were found over hard-low habitats at 4 of the 6 sampled locations. We recorded Opakapaka as small as $16 \mathrm{~cm}$ FL within our sampling depths over hard-low habitats. On the basis of growth curves from DeMartini et al. (1994), the juvenile Opakapaka in our study were just under 1 year old and could be recent migrants from a surrounding nursery area. The results of this study show that these fish continue to stay in hard-low habitats until they reach $45 \mathrm{~cm} \mathrm{FL}$ or about 5 years of age and, thereafter, increasingly use hard-high habitats. It is possible that this species uses hard substrates with low slopes as a transitional habitat before a move into hard-high habitats. Opakapaka reaches sexual maturity at $\sim 43 \mathrm{~cm} \mathrm{FL} \mathrm{(Kikkawa,} \mathrm{1984).} \mathrm{The}$ shift in habitat from hard-low to hard-high could be a response to reproductive maturity, which is discussed later.

Size-related habitat shifts also were evident for Kalekale and Onaga but were observed without a change in their depth of occurrence. Previous studies also showed a lack of depth change with size for these species (Kelley et $\mathrm{al}^{4}$; Ikehara, 2006). The move into hard-high habitats with increasing size coincided roughly with the onset of sexual maturity in both species. The size (25-35 cm FL) at which Kalekale shifted

\footnotetext{
${ }^{4}$ Kelley, C. D., B. C. Mundy, and E. G. Grau. 1997. The use of the Pisces V submersible to locate nursery grounds of commercially important deepwater snappers, family Lutjanidae, in Hawaii, 62 p. Paper presented at the $5^{\text {th }}$ Indo-Pacific Fish Conference; Nouméa, New Caledonia, 10-16 November.
}

to hard-high habitats from other types includes the size $(29 \mathrm{~cm} \mathrm{FL})$ at which this species reaches sexual maturity (DeMartini and Lau, 1999). The onset of sexual maturity for Onaga occurs at $61 \mathrm{~cm} \mathrm{FL} \mathrm{(Everson} \mathrm{et} \mathrm{al.,}$ 1989) - a size larger than the size ( $55 \mathrm{~cm} \mathrm{FL)} \mathrm{at} \mathrm{which}$ a shift in habitat use was observed in our study. On the basis of size-at-age curves, the onset of sexual maturity occurs between the ages of 3 and 6 years for Kalekale (Williams and Lowe, 1997) and 5 to 6 years for Onaga (Everson et al., 1989).

In contrast to the other 3 species, no size-related habitat shifts were observed for Ehu, but very few juveniles of this species were measured (Fig. 6;n=37). Juvenile Ehu, along with other smaller bottomfishes, are highly vulnerable to predation by demersal carnivores, such as the Greater Amberjack (Seriola dumerili) (Humphreys and Kramer, 1984). A few instances where Greater Amberjack seemed to scare away Kalekale and Ehu were observed in the BotCam video collected during our study. No aggressive behavior toward the target species by other predators was seen, but it is possible that carnivorous species could have affected our ability to sample certain size ranges of bottomfishes, particularly Ehu. Smaller snappers may have moved out of the BotCam's field of view before predators entered. Even if they were possibly in the vicinity of the BotCam, juveniles may have remained close to the bottom of the seafloor for protection and out of the unit's field of view. Until very small Ehu (i.e., 5-15 cm FL) can be observed regularly, a complete ontogenetic assessment of habitat for this species will not be possible. However, it is important to note that the size range of Ehu harvested by the fishery is represented in this study.

The ontogenetic habitat shifts observed for Opakapaka, Kalekale, and Onaga could be related to shifts in diet, increases in reproductive output, and predator avoidance at smaller sizes. Szedlmayer and Lee (2004) reported a shift in the diet of the shallow-water juvenile Red Snapper (Lutjanus campechanus) from crustaceans to fishes and cephalopods with increasing size. This change in diet was associated with the migration from nursery habitats to coral reefs. For deepwater snappers, diet shifts have yet to be documented. DeMartini et al. (1996) examined the diet of juvenile Opakapaka from the nursery in Kaneohe Bay and discovered that it was composed of crustaceans (shrimps and stomatopods), gelatinous organisms (salps and heteropods), nekton (fishes and squids), and benthic organisms (demersal octopods, echinoids, and microgastropods). With the exception of benthic prey, a similar diet was found for Opakapaka caught at depths of 100-300 m in Penguin Bank by Haight et al. (1993b). It is possible that smaller individuals $(<43 \mathrm{~cm} \mathrm{FL})$ of this species associate with low-sloping, hardbottom habitats to feed on the benthos and then shift to a pelagic diet when they move into hard-high habitats where the postulated increase in water flow increases prey availability (Ralston et al., 1986; Haight et al., 1993a; Kelley et al., 2006). 
With the hypothesis that the levels of bottomfish prey and current speed are greater over hard-high habitats than over other environments (Ralston et al., 1986; Haight et al., 1993a; Kelley et al., 2006), it could be inferred that Opakapaka, Kalekale, and Onaga move into this habitat type upon reaching sexual maturity to increase their foraging rates and maximize reproductive output and gamete dispersal. On coral reefs in Hawaii, the Yellow Tang (Zebrasoma flavescens) has been found to shift into habitats with increased food resources when it reaches reproductive size to possibly improve its reproductive ability (Claisse et al., 2009). No actual bottomfish spawning events were recorded during our study. Opakapaka and Onaga are known to spawn at night (C. Kelley, unpubl. data), and camera deployments were restricted to daytime hours. Other than seasonality, habitat and environmental parameters of bottomfish spawning have yet to be determined. It remains possible, however, that the observed ontogenetic habitat shifts occurred as a result of a reproductive cue-given that the change in habitat roughly coincided with sexual maturity.

Another factor that may influence ontogenetic habitat shifts is habitat complexity. Laidig et al. (2009) found that juvenile rockfishes on the continental shelf off central California were associated with boulder and cobble habitats before they moved into the slope habitats used by adults. It is plausible that juveniles and smaller species of bottomfishes use more complex habitats in a similar manner for protection and predator avoidance. However, because habitats were classified at a 200-m scale, our study did not take into account habitat heterogeneity within grid cells and smaller-scale habitat characteristics, such as complexity or rugosity. Structural complexity and the combination of habitat types in a given area are likely to influence fish distributions at their respective scales. Future work is needed to investigate the role of habitat complexity and heterogeneity on size distributions of bottomfishes and to look more closely into how specific habitat types are used. Such an approach could provide more information about the cause of the ontogenetic habitat shifts observed in this study.

The regional variations in relative abundance and mean length could be related to differential fishing pressure or large-scale habitat features. It can be expected that remote locations, such as Niihau, would have less fishing pressure than locations closer to major ports and, thereby, would have greater relative abundances and lengths of target species. Contrary to this expectation, the highest levels of relative abundance were found at Hilo for Opakapaka and in Pailolo Channel for Ehu. Both areas are easily accessible to fishing; therefore, other factors may have driven the observed distributions. Protection did not have an influence on the relative abundance of any of the 4 species studied, a finding that is consistent with the results of Moore et al. (2013). In terms of mean length, the largest Opakapaka may have been found at Niihau because of the remote location and longevity of the protection of this small island. The Niihau BRFA has been closed to fishing since 1998. The opposite may be true for Hilo, where the smallest Opakapaka were observed. Before the implementation of the revised system of BRFAs, fishing in the depth range of Opakapaka was permitted because the BRFA boundary began at $200 \mathrm{~m}$. How protection and fishing pressure affect abundance and size distributions of bottomfishes should be investigated further because these factors may confound any trends attributed to habitat or other environmental variables.

Mega-scale habitat features (scale from Greene et al., 1999: macro=1-10 m; meso $=10-1000 \mathrm{~m} ;$ mega $=1-10$ $\mathrm{km}$ ), such as pinnacles, banks, terraces, and even featureless carbonate flats, also could be influencing bottomfish distributions. In this study, juvenile Opakapaka and Onaga were found to associate with hard-low habitats. There is a large terrace at Hilo, where most juvenile Opakapaka were observed, and flat, hardbottom habitats predominate in Pailolo Channel, where most Onaga juveniles were present. These large-scale features predominantly have low slopes and hard bottoms and match the observed habitat preference of these species at the meso-scale. However, because of the difference between the habitat classification scale $(200 \times 200 \mathrm{~m})$ used in our study and the size of megascale features, further investigation is required to establish a conclusive connection between the bottomfish distributions observed in this study and mega-scale features. In the case of Pailolo Channel, for example, with its large, flat areas of hardbottom habitat, our results agreed with a finding of another survey effort. Previous fishing surveys have indicated that this area possibly was a nursery ground for Onaga (C. Kelley, unpubl. data). Because the smallest mean length $(42.80$ $\mathrm{cm} \mathrm{FL)} \mathrm{and} \mathrm{about} 75 \%$ of all juveniles of this species measured $(<61 \mathrm{~cm} \mathrm{FL})$ in this study came from Pailolo Channel, it is highly likely that a nursery ground for Onaga exists in this area.

\section{Conclusions}

This study has improved our understanding of the species-specific ecology of 4 bottomfish species in the MHI. Analyses of habitat preferences on the basis of relative abundance and length-frequency distributions showed that habitat types other than hard-high environments are important to each of the species studied, often as a result of ontogenetic shifts in habitat use. Given that these bottomfishes are found throughout the Indo-Pacific region, these findings may provide the framework for the prediction of species distributions outside of Hawaii. Because juveniles of Opakapaka and Onaga were associated mostly with hard-low habitats, it is imperative that future definitions of the bottomfish EFH take into account habitat associations by life stage. Although some species share similar preferences, 
it also is clear that bottomfish distributions are species-specific and cannot be generalized for all members of the bottomfish fishery in Hawaii. Because it has increased our knowledge of the ecology of individual species, the results of this study can aid in the improvement of ecosystem-based management strategies and definitions of species-specific EFHs. Moving forward, to further improve our understanding of the habitat requirements of bottomfish species in Hawaii, research on bottomfish habitat should focus on development of models to determine the dispersal range of bait-odor plumes, identification of the effective scale of attraction to bait stations, standardization of sampling areas, and inclusion of habitat heterogeneity and macroscale habitat characteristics in future analyses of bottomfish distributions.

\section{Acknowledgments}

We would like to thank C. Moore, D. Sackett, and F. DeLeo for input on statistical design and testing; C. Demarke, B. Alexander, J. Yeh, J. Friedman, and B. Schumacher for many hours of field operations and video analysis; D. Merritt, K. Wong, and the Coral Reef Ecosystem Division of the NOAA Pacific Islands Fisheries Science Center for giving us access to BotCam units; J. Ault, S. Smith, M. Parke, G. DiNardo, and J. Brodziak for assistance with the experimental design; and captains R. Cates (Wailoa) and G. Jones (Red Raven; Huki Pono). This project was funded by the State of Hawaii DLNR-DAR and in part by the Federal Aid in Sport Fish Restoration Program.

\section{Literature cited}

Anderson, M. J., R. N. Gorley, and K. R. Clarke.

2008. PERMANOVA+ for PRIMER: Guide to software and statistical methods. PRIMER-E Ltd, Plymouth, UK.

Andrews, A. H., J. M. Kalish, S. J. Newman, and J. M. Johnston. 2011. Bomb radiocarbon dating of three important reeffish species using Indo-Pacific $\Delta^{14} \mathrm{C}$ chronologies. Mar. Freshw. Res. 62:1259-1269.

Andrews, A. H., E. E. DeMartini, J. Brodziak, R. S. Nichols, and R. L. Humphreys.

2012. A long-lived life history for a tropical, deepwater snapper (Pristipomoides filamentosus): bomb radiocarbon and lead-radium dating as extensions of daily increment analyses in otoliths. Can. J. Fish. Aquat. Sci. 69:1-20.

Cappo, M. C., E. S. Harvey, H. A. Malcolm, and P. J. Speare. 2003. Potential of video techniques to design and monitor diversity, abundance and size of fish in studies of marine protected areas. In Aquatic protected areaswhat works best and how do we know? World congress on aquatic protected areas; Cairns, Australia, 14-17 August 2002 (J. P. Beumer, A. Grant, and D. C. Smith, eds.), p. 455-464. Austr. Soc. Fish Biol., North Beach, Western Australia, Australia.
Claisse, J. T., M. Kienzle, M. E. Bushnell, D. J. Shafer, and J. D. Parrish.

2009. Habitat- and sex-specific life history patterns of yellow tang Zebrasoma flavescens in Hawaii, USA. Mar. Ecol. Prog. Ser. 389:245-255.

DeMartini, E. E., K. Landgraf, and S. Ralston.

1994. A recharacterization of the age-length and growth relationships of the Hawaiian snapper, Pristipomoides filamentosus. NOAA Tech. Memo. NMFS-SWFSC-199, $15 \mathrm{p}$.

DeMartini, E. E., and B. B. Lau.

1999. Morphometric criteria for estimating sexual maturity in two snappers, Etelis carbunculus and Pristipomoides sieboldii. Fish. Bull. 97:449-458.

DeMartini, E. E., F. A. Parrish, and D. M. Ellis.

1996. Barotrauma-associated regurgitation of food: implications for diet studies of Hawaiian pink snapper, Pristipomoides filamentosus (family Lutjanidae). Fish. Bull. 94:250-256.

Ellis, D. M., and E. E. DeMartini.

1995. Evaluation of a video camera technique for indexing abundances of juvenile pink snapper, Pristipomoides filamentosus, and other Hawaiian insular shelf fishes. Fish. Bull. 93:67-77.

Everson, A. R.

1986. Ehu. In Fishery atlas of the Northwestern Hawaiian Islands (R. Uchida and J. H. Uchiyama, eds.), p. 106-107. NOAA Tech. Rep. NMFS 38, 142 p.

Everson, A. R., H. A. Williams, and B. M. Ito.

1989. Maturation and reproduction in two Hawaiian eteline snappers, uku, Aprion virescens, and onaga, Etelis coruscans. Fish. Bull. 87:877-888.

Greene, H. G., M. M. Yoklavich, R. M. Starr, V. M. O'Connell, W. W. Wakefield, D. E. Sullivan, J. E. McRea Jr., and G. M. Cailliet.

1999. A classification scheme for deep seafloor habitats. Oceanol. Acta 22:663-678.

Haight, W. R.

1989. Trophic relationships, density and habitat associations of deepwater snappers (Lutjanidae) from Penguin Bank, Hawaii. M.S. thesis., 86 p. Univ. Hawaii, Honolulu, HI.

Haight, W. R., D. R. Kobayashi, and K. E. Kawamoto.

1993a. Biology and management of deepwater snappers of the Hawaiian Archipelago. Mar. Fish. Rev. 55(2):20-27.

Haight, W. R., J. D. Parrish, and T. A. Hayes.

1993b. Feeding ecology of deepwater lutjanid snappers at Penguin Bank, Hawaii. Trans. Am. Fish. Soc. 122:328-347.

Harvey, E. S., M. Cappo, J. J. Butler, N. Hall, and G. A. Kendrick.

2007. Bait attraction affects the performance of remote underwater video stations in assessment of demersal fish community structure. Mar. Ecol. Prog. Ser. 350:245-254.

Humphreys, R. L., and S. H. Kramer.

1984. Ciguatera and the feeding habits of the greater amberjack, Seriola dumerili, in the Hawaiian Archipelago. In Proceedings of the second symposium on resource investigations in the Northwestern Hawaiian Islands, vol. 2; Honolulu, 25-27 May 1983 (R. W. Grigg and K. Y. Tanoue, eds.), p. 237-264. Univ. Hawaii Sea Grant College Program, Honolulu, HI. 
Ikehara, W.

2006. Bottomfish management and monitoring in the main Hawaiian Islands. In Deep sea 2003: conference on the governance and management of deep-sea fisheries. Part 2: conference poster papers and workshop papers; Queenstown, New Zealand, 1-5 December 2003, Dunedin, New Zealand, 27-29 November 2003 (R. Shotton, ed.), p. 289-300. FAO Fisheries Proceedings 3/2. FAO, Rome.

Kelley, C., R. Moffitt, and J. R. Smith.

2006. Mega- to micro-scale classification and description of bottomfish essential fish habitat on four banks in the Northwestern Hawaiian Islands. Atoll Res. Bull. 543:319-332.

Kikkawa, B. S.

1984. Maturation, spawning, and fecundity of opakapaka, Pristipomoides filamentosus, in the Northwestern Hawaiian Islands. In Proceedings of the second symposium on resource investigations in the Northwestern Hawaiian Islands, vol. 2; Honolulu, 25-27 May 1983 (R. W. Grigg and K. Y. Tanoue, eds.), p. 149-160. Univ. Hawaii Sea Grant College Program, Honolulu, HI.

Laidig, T. E., D. L. Watters, and M. M. Yoklavich.

2009. Demersal fish and habitat associations from visual surveys on the central California shelf. Estuar. Coast. Shelf Sci. 83:629-637.

Merritt, D. W.

2005. BotCam: Design, testing and development of a fully automated stereo-video bottom camera bait station for ecosystem monitoring of bottom fish species. M.S. thesis, 174 p. Univ. Hawaii, Honolulu, HI.

Merritt, D. W., M. K. Donovan, C. Kelley, L. Waterhouse, M.

Parke, K. Wong, and J. C. Drazen.

2011. BotCam: a baited camera system for nonextractive monitoring of bottomfish species. Fish. Bull. 109:56-67.

Moffitt R. B., and F. A. Parrish.

1996. Habitat and life history of juvenile Hawaiian pink snapper, Pristipomoides filamentosus. Pac. Sci. 50:371-381.

Moore, C. H., J. C. Drazen, C. D. Kelley, and W. F. X. E. Misa. 2013. Deepwater marine protected areas of the main Hawaiian Islands: establishing baselines for commercially valuable bottomfish populations. Mar. Ecol. Prog. Ser. 476:167-183.

Parke, M.

2007. Linking Hawaii fishermen reported commercial bottomfish catch data to potential bottomfish habitat and proposed restricted fishing areas using GIS and spatial analysis. NOAA Tech. Memo. NMFS-PIFSC-11, $37 \mathrm{p}$.

Parrish, F. A.

1989. Identification of habitat of juvenile snappers in Hawaii. Fish. Bull. 87:1001-1005.

Parrish, F. A., E. E. DeMartini, and D. M. Ellis.

1997. Nursery habitat in relation to production of juvenile pink snapper, Pristipomoides filamentosus, in the Hawaiian Archipelago. Fish. Bull. 95:137-148.
Parrish, J. D.

1987. The trophic biology of snappers and groupers. In Tropical snappers and groupers: biology and fisheries management (J. J. Polovina and S. Ralston, eds.), p. 405-463. Westview Press, Boulder, CO.

Priede, I. G., and N. R. Merrett.

1996. Estimation of abundance of abyssal demersal fishes; a comparison of data from trawls and baited cameras. J. Fish Biol. 49(suppl. A):207-216.

Polovina, J. R., R. B. Moffitt, S. Ralston, P. M. Shiota, and H. A. Williams.

1985. Fisheries resource assessment of the Mariana Archipelago, 1982-85. Mar. Fish. Rev. 47(4):19-25.

Ralston, S., R. M. Gooding, and G. M. Ludwig.

1986. An ecological survey and comparison of bottom fish resource assessments (submersible versus handline fishing) at Johnston Atoll. Fish. Bull. 84:141-155.

Ralston, S., and J. R. Polovina.

1982. A multispecies analysis of the commercial deepsea handline fishery in Hawaii. Fish. Bull. 80:435-448.

Randall, J. E.

2007. Reef and shore fishes of the Hawaiian Islands, 546 p. Univ. Hawaii Sea Grant College Program, Honolulu, HI.

Rosenberg, A., T. E. Bigford, S. Leathery, R. L. Hill, and K. Bickers.

2000. Ecosystem approaches to fishery management through essential fish habitat. Bull. Mar. Sci. 66:535-542.

Szedlmayer, S. T., and J. D. Lee.

2004. Diet shifts of juvenile red snapper (Lutjanus campechanus) with changes in habitat and fish size. Fish. Bull. 102:366-375.

Watson D. L., E. S. Harvey, B. M. Fitzpatrick, T. J. Langlois, and G. Shedrawi.

2010. Assessing reef fish assemblage structure: how do different stereo-video techniques compare? Mar. Biol. 157:1237-1250

Williams, H. A., and M. K. Lowe.

1997. Growth rates of four Hawaiian deep slope fishes: a comparison of methods for estimating age and growth from otolith micro-increment widths. Can. J. Fish. Aquat. Sci. 54:126-136.

Willis, T. J., and R. C. Babcock.

2000. A baited underwater video system for the determination of relative density of carnivorous reef fish. Mar. Freshw. Res. 51:755-763.

Willis, T. J., R. B. Millar, and R. C. Babcock.

2000. Detection of spatial variability in relative density of fishes: comparison of visual census, angling, and baited underwater video. Mar. Ecol. Prog. Ser. 198:249-260.

Yau, C., M. A. Collins, P. M. Bagley, I. Everson, C. P. Nolan, and I. G. Priede.

2001 Estimating the abundance of Patagonian toothfish, Dissostichus eleginoides, using baited cameras: a preliminary study. Fish. Res. 51:403-412. 